
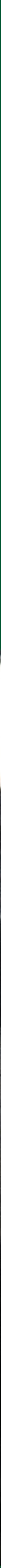

journals.cambridge.org/ags 


\section{The Journal of Agricultural Science}

\section{SENIOR EDITORS}

Dr. P. Bilsborrow

University of Newcastle, School of Agriculture, Food \& Rural

Development, Newcastle upon Tyne NE1 7RU, UK

Prof. J. Wiseman

University of Nottingham, School of Biosciences, Sutton Bonington

Campus, Loughborough, Leicestershire LE12 5RD, UK

\section{EDITORIAL BOARD}

T. Aveling, University of Pretoria, South Africa

B. Barkla, Universidad Nacional Autónoma de México, México

S. C. Bishop, Roslin Institute, Edinburgh, UK

M. D. Casler, US Dairy Forage Research Center, Madison, USA

S. Ceccarelli, ICARDA, France

A. Cobb, Sedbergh, UK

B. R. Cullis, University of Wollongong, Australia

J. Dijkstra, Wageningen University, The Netherlands

R. Dinkins, USDA-ARS, USA

\section{SUBMISSIONS}

The Journal has moved to electronic submission. Manuscripts should be uploaded to http://mc.manuscriptcentral.com/jagricsci. Double-blind refereeing has also been adopted, therefore the authors' names, addresses and emails should be removed from the main document and uploaded as a title page in a separate file, tagged 'Not for Review'. Help is available on the website.

\section{SUBSCRIPTIONS}

The Journal of Agricultural Science (ISSN 0021-8596) is published six times a year in February, April, June, August, October and December. Six parts form a volume. The subscription price (excluding VAT) of Volume 151 (2013) (which includes delivery by air where appropriate, plus electronic access to institutional subscribers) is $£ 997$ net (US \$1660 in the USA, Canada and Mexico). Single parts are $£ 142$ net (US \$251 in the USA, Canada and Mexico. The electronic only price available to institutional subscribers is $£ 740$ (\$1270 in USA, Canada and Mexico). Back issues are also available.

Orders, which must be accompanied by payment, may be sent to a bookseller, subscription agent or direct to the publisher: Cambridge University Press, The Edinburgh Building, Shaftesbury Road, Cambridge CB2 8RU, UK; or in the USA, Canada and Mexico: Cambridge University Press, Journals Fulfillment Department, 100 Brook Hill Drive, West Nyack, New York 10994-2133. EU subscribers (outside the UK) who are not registered for VAT should add VAT at their country's rate. VAT registered subscribers should provide their VAT registration number. Japanese prices for Institutions are available from Kinokuniya Company Ltd, PO Box 55, Chitose, Tokyo 156, Japan.

POSTMASTER: send address changes in the USA, Canada and Mexico to: The Journal of Agricultural Science, Cambridge University Press, 100 Brook Hill Drive, West Nyack, New York 10994-2133. Claims for missing issues should be made immediately on receipt of the subsequent issue.
R. N. Edmondson, Warwick HRI, Wellesbourne, UK

J. Eitzinger, University of Natural Resources and Applied Life Sciences (BOKU), Vienna

W. Erskine, CLIMA, University of Western Australia, Australia J. France, University of Guelph, Canada

G. Hoogenboom, Washington State University, USA

R. Hunter, CSIRO Animal, Food and Health Sciences, Queensland, Australia

A. Kohli, IRRI, Manila, the Philippines

J. Lauren, Cornell University, Ithaca, NY USA

S. Lopez, Universidad de León, Spain

S. Orlandini, University of Florence, Italy

C. K. Reynolds, University of Reading, UK

J. A. Rooke, SAC, Edinburgh, UK

U. R. Sangakkara, University of Peradeniya, Sri Lanka

D. Sparkes, Nottingham University, UK

N. St. Pierre, Ohio State University, USA

C. Watson, Scottish Agricultural College, Aberdeen, UK

F. Xu, Huazhong Agricultural University, China

\section{COPYING}

No contents may be reproduced by any means without the permission of Cambridge University Press. This journal is registered with the Copyright Clearance Center, 222 Rosewood Drive, Danvers, MA 01923, USA (www.copyright.com). Organizations in the USA who are also registered with the CCC may therefore copy material (beyond the limits permitted by sections 107 and 108 of US copyright law) subject to payment to CCC. This consent does not extend to multiple copying for promotional or commercial purposes. ISI Tear Sheet Service, 3501 Market Street, Philadelphia, PA 19106, USA, is authorized to supply single copies of separate articles for private use only. Organizations authorized by the Copyright Licensing Agency may also copy material subject to the usual conditions. For all other use, permission should be sought from Cambridge or the American Branch of Cambridge University Press.

\section{INTERNET ACCESS}

This journal is included in the Cambridge Journals Online service which can be found at http://www.journals.cambridge.org For further information on other Press titles access www.cambridge.org

This journal issue has been printed on FSC-certified paper and cover board. FSC is an independent, non-governmental, not-for-profit organization established to promote the responsible management of the world's forests. Please see www.fsc.org for information.

\section{CAMBRIDGE UNIVERSITY PRESS}

The Edinburgh Building, Shaftesbury Road, Cambridge CB2 8RU, United Kingdom

32 Avenue of the Americas, New York, NY 10013-2473, USA 477 Williamstown Road, Port Melbourne, VIC 3207, Australia Ruiz de Alarcón 13, 28014 Madrid, Spain Dock House, The Waterfront, Cape Town 8001, South Africa 